\title{
FAKTOR-FAKTOR YANG MEMPENGARUH TERHADAP TINGKAT DEPOSIT BANK UMUM SYARIAH PERIODE 2011-20181
}

\author{
Sri Fatimah Luliansari \\ Departemen Ekonomi Syariah-Fakultas Ekonomi dan Bisnis-Universitas Airlangga \\ Email: Sri.fatimah.Iuliansari-2015@feb.unair.ac.id

\section{Dian Filianti} \\ Departemen Ekonomi Syariah-Fakultas Ekonomi dan Bisnis-Universitas Airlangga \\ Email: dianfilianti@feb.unair.ac.id
}

\begin{abstract}
This study aims to determine the effect of partial and simultaneous variables of Capital Adequacy Ratio (CAR), Non Performing Financing (NPF), and Deposit Insurance System (DIS) on Deposit Rates of Islamic commercial banks in the 2011-2018 period. The data used in this study are secondary data from the Financial Services Authority Report and Sharia Banking Annual Report 2010-2018. The analytical method used in this study is the penel data regression analysis test, where the sample used amounted to 11 Islamic commercial banks obtained by purposive sampling method. The results of the analysis of the best model data used by the author are the Fixed Effect Model. On the results of this researchers simultaneously all variables affect the level of Islamic commercial bank deposits. But partially the CAR and NPF variables have a positive effect on the deposit rate while the DIS does not affect the deposit rate.
\end{abstract}

Keywords: Capital Adequacy Ratio (CAR), Non Performing Financing (NPF), Deposit Insurance system (DIS), Tingkat Deposit

\section{PENDAHULUAN}

Stabilitas industri perbankan mempengaruhi stabilitas perekonomian secara keseluruhan. Pada tahun 19971998 krisis moneter dan perbankan yang menghantam Indonesia yang ditandai dengan Bank Indonesia dibantu International Monetary Fund (IMF) melikuidasi 16 bank tanpa jaminan simpanan mengakibatkan, terjadinya bank runs pada beberapa bank swasta dan kerugian yang mencapai setengah Pendapatan Domestik Bruto (PDB) Indonesia. Pemerintah melalui Bank Indonesia mencetak uang lebih banyak dan menaikkan suku bunga agar mampu menarik dana dari masyarakat (Sejarah
Moneter Indonesia, BI, 2019). Caprio dan Klingbiel (1999), melakukan studi mengenai krisis dan menemukan krisis perbankan di dunia berujung kepada 112 krisis sistematik dan 51 krisis non sistemik. Terdapat beberapa strategi yang dapat dijalankan untuk meredam dampak sistemik dari krisis perbankan, salah satunya berupa implementasi sistem penjamin simpanan baik secara implisit maupun eksplisit (Kunt dan Kene, 2002). Krisis multidimensi ini menyebabkan penurunan nilai rupiah, likuidasi 16 bank dan penurunan kepercayaan publik akan sistem perbankan nasional (Dody dan Soepomo, 2013).

\footnotetext{
${ }^{1}$ Jurnal ini merupakan bagian dari skripsi dari Sri Fatimah Luliansari, NIM: 04151 1433035, yang diuji pada 21 Oktober 2019.
} 
Luliansari, et al/Jurnal Ekonomi Syariah Teori dan Terapan Vol. 6 No. 12 Desember 2019: 2451-2470; FAKTOR-FAKTOR YANG MEMPENGARUH TERHADAP TINGKAT DEPOSIT BANK UMUM SYARIAH PERIODE 2011-2018

Fungsi intermediasi yang dimiliki oleh bank ditunjukkan oleh proses penghimpun dana dalam bentuk deposit dan kemudian di salurkan kembali dalam bentuk pinjaman (Allen dan Santomero, 1997). Ketika bank menghimpun dana deposit lebih banyak maka dana yang disalurkan ke masyarakat dalam bentuk pinjaman akan semakin lebih besar. Menurut penelitian yang dilakukan oleh Chernykh dan Cole (2010) menghasilkan penelitian bank yang menjadi bagian dari anggota penjaminan simpanan menghimpun deposit dari masyarakat dengan jumlah yang lebih besar, sedangkan bank yang tidak menjadi anggota penjaminan simpanan menghimpun deposit dalam jumlah yang lebih sedikit.

Pertumbuhan jumlah DPK juga menunjukan semakin banyaknya masyarakat yang menyimpan dananya di bank-bank syariah. Hal ini juga menunjukan tingkat kepercayaan masyarakat pada bank syariah. Bank Indonesia sebagai regulator yang berwenang melakukan fungsi pengawasan terhadap perbankan hingga 31 Desember 2013 berupayah menjaga kestabilan sistem perbankan dengan menerapkan berbagai regulasi. Salah satunya adalah dengan melakukan pembinaan dan pengawasan bank dengan menetapkan ketentuan tentang kesehatan bank, memperhatikan aspek permodalan, kualitas aseet, kualitas manajemen, rentabilitas, likuiditas dan solvabilitas serta aspek lain yang berhubungan dengan usaha bank baik dari eksternal maupun internal bank. Modal merupakan komponen yang peting dalam pengembangan usaha bisnis dan menampung risiko kerugian, semakin tinggi Capital Adequacy Ratio (CAR), maka semakin kuat kemampuan bank untuk menanggung risiko dari setiap kredit/aktiva produktif yang berisiko.

Tingkat nilai CAR yang tinggi (sesuai ketentuan BI 8\%) maka bank tersebut mampu membiayai operasi bank, keadaan tersebut memberikan kontribusi yang besar bagi profitabilitas dan meningkatkan return bagi hasil yang diterima nasabah deposan (Kuncoro \& Suhardjono, 2002). Penelitian Sofyan, Idqan dan Irfan (2017) menghasilkan penelitian CAR secara signifikan mempengaruhi tingkat variabel deposito secara negativehasil ini sejalan dengan Rokhim dan Wulandary (2012). Selama periode pengamatan, CAR bank syariah tinggi karena ada suntikan modal dari pemegang saham sebagai bagian dari pemenuhan peraturan terkait dengan modal minimum bank syariah. Berdasarkan data dari laporan bank, rasio CAR tertinggi didominasi oleh bank terkecil dalam aset dengan rata-rata berkisar antara $36,40 \%$ hingga $70,84 \%$. Ini sebagai akibat dari ketidakmampuan bank untuk mengucurkan pembiayaan. Ini harus memberikan keamanan bagi deposan karena bank memiliki cadangan 
Luliansari, et al/Jurnal Ekonomi Syariah Teori dan Terapan Vol. 6 No. 12 Desember 2019: 2451-2470; FAKTOR-FAKTOR YANG MEMPENGARUH TERHADAP TINGKAT DEPOSIT BANK UMUM SYARIAH PERIODE 2011-2018

modal yang cukup untuk mencegah bank gagal bayar.

Non Performing Financing (NPF) pada perbankan syariah yaitu jumlah pembiayaan yang tergolong non lancar dengan kualitas kurang lancar, diragukan dan macet (Muhammad, 2005).

Financing to Deposit Ratio (FDR) yakni rasio pembiayaan terhadap dana pihak ketiga yang menggambarkan sejauh mana simpanan dapat digunakan untuk mengukur tingkat likuiditas perbankan syariah dengan membandingkan jumlah kredit yang disalurkan dengan jumlah deposit yang dimiliki. Semakin tinggi rasio, maka tingkat likuiditas bank akan semakin rendah, karena jumlah dana yang digunakan untuk membiayai kredit semakin kecil, demikian pula sebaliknya (Kasmir, 2007). Namun apabila FDR perbankan syariah meningkan dan melebihi ketentuan BI, maksimal $110 \%$ maka bank akan meningkatkan target perolehan dananya. Dalam jangka pendek bank akan menaikkan return bagi hasil untuk menarik nasabah baru yang akan menginvestasikan dananya di bank syariah. Ketika pendapatan naik laba juga akan mengalami kenaikan. Laba yang tinggi akan meningkatkan jumlah bagi hasil yang akan dibagikan kepada nasabah.

Terkait dengan stabilitas perbankan pemerintah bersama Bank Indonesia (BI) sebagai bank sentral, Lembaga Penjamin Simpanan (LPS) dan
Otoritas Jasa Keuangan (OJk) berupaya menjaga melalui regulasi seperti kebijakan rasio kecukupan modal (CAR), batas maksimum non performing financing (NPF), rasio pembiayaan terhadap pihak ketiga (FDR). Berdasarkan hal tersebut peneliti ingin mengkaji apakah dampak regulasi Deposit Insurance system (DIS), Capital Adequacy Ratio (CAR), Financing to Deposit Ratio (FDR), dan Non performing Financing (NPF) berpengaruh terhadap tingkat deposit Bank Umum Syariah.

\section{LANDASAN TEORI}

Pada tahun 1963 dibentuk sebuah Lembaga kevangan pedesaa yang bernama Mit Ghamr Savings Bank atau biasa disebut Mit Ghamr Bank yang di pelopori oleh seorang ekonom bernama Dr. Ahmad El Najjar. Lembaga keuangan tersebut dalam operasinya tidak membebankan bunga pada peminjam maupun membayar bunga kepada penabung, serta melakukan investasi secara langsung maupun dalam bentuk kemitraan dengan pihak lain dan membagi keuntungan dengan para penabung. Keberhasilan Bank syariah pertama, mit Ghamr Bank menginspirasi banyak pihak untuk melakukan hal yang sama. Pemerintahan Mesir di bawah pemerintah Gamal Abdul Naser membentuk Naser Social Investment dengan basis perkoyaan pada tahun 1972. Masyarakat cendikiawan dan professional di filipina membentuk Bank Amanah pada tahun 1973. Kemudian 
Luliansari, et al/Jurnal Ekonomi Syariah Teori dan Terapan Vol. 6 No. 12 Desember 2019: 2451-2470; FAKTOR-FAKTOR YANG MEMPENGARUH TERHADAP TINGKAT DEPOSIT BANK UMUM SYARIAH PERIODE 2011-2018

Organisasi Konferensi Islam (OKI) yang beranggotakan berbagai negara berpenduduk muslim bersepakat untuk mendirikan Islamic Development Bank (IDB) pada tahun 1973 di Jeddah.

IDB didirikan dengan tujuan mendorong kemajuan pembangunan ekonomi dan sosial negara-negara anggota dan komunitas Muslim secara bersama-sama berdasarkan prinsip-prinsip syariah Islam. IDB berkontribusi terhadap perkembangan perbankan syariah dengan memfasilitasi berbagai riset dan pengembangan (R\&D) dalam bidang ekonomi, keuangan, dan perbankan islam. Penyertaan modal maupun kepemikian saham pada bank syariah pun dilakukan oleh IDB untuk mendukung perkembangan bank syariah di negara lain. Berdirinya Bank Muamalat Indonesia (BMI) didukung oleh saham IDB dengan komposisi sebanyak $16,02 \%$ sejak tahun 1999.

Menurut Undang-Undang Republik Indonesia No. 21 Tahun 2008, Perbankan Syariah adalah segala sesuatu yang menyangkut tentang Bank Syariah dan Unit Usaha Syariah, mencakup kelembagaan, kegiatan usaha, serta cara dan proses dalam melaksanakan kegiatan usahanya. Pada dasarnya ketiga fungsi utama perbankan (menerima titipan dana, meminjamkan vang, dan jasa pengiriman vang) adalah boleh dilakukan, kecuali bila dalam melaksanakan fungsi perbankan melakukan hal-hal yang dilarang syariah.
Dalam praktik perbankan konvesional yang dikenal saat ini, fungsi tersebut dilakukan berdasarkan prinsip bunga. Menurut undang-undang nomer 10 tahun 1998 maupun dalam undang-undang nomer 21 tahun 2008 dijelaskan bahwa "syariah adalah aturan berdasarkan hukum islam". Ketentuan syariah didasarkan dari hukum islam yang dituangkan dalam suatu ketentuan yang dikeluarkan oleh Majelis Ulama Indonesia yang disebut "Fatwa dewan syariah nasional". Fatwa ini digunakan sebagai referensi dalam melaksanakan kegiatan Bank Syariah.

Pembiayaan berdasarkan prinsip syariah adalah penyediaan vang atau tagihan yang dipersamakan dengan itu berdasarkan persetujuan atau kesepakatan antara bank dengan pihak lain yang mewajibkan pihak yang dibiayai untuk mengendalikan uang dantagihan tersebut setelah jangka waktu tertentu dengan imbalan atau bagi hasil. Prinsip syariah adalah aturan perjanjian berdasarkan hukum Islam antara bank dan pihak lain untuk penyimpanan dana atau pembiayaan kegiatan usaha dan/atau kegiatan lainnya yang dinyatakan sesuai syariah, antara lain pembiayaan berdasarkan prinsip bagi hasil (mudharabah), pembiayaan dengan prinsip penyertaan modal (musyarakah), prinsip jual beli barang dengan memperoleh keuntungan (murabahah), pembiayaan barang modal berdasarkan prinsip sewa murni tanpa pilihan (ijarah), 
Luliansari, et al/Jurnal Ekonomi Syariah Teori dan Terapan Vol. 6 No. 12 Desember 2019: 2451-2470; FAKTOR-FAKTOR YANG MEMPENGARUH TERHADAP TINGKAT DEPOSIT BANK UMUM SYARIAH PERIODE 2011-2018

atau adanya pilihan pemindahan pemilikan atau barang yang disewa dari pihak bank oleh pihak lain (ijarah wa iqtima).

Industri perbankan syariah, pelarangan terhadap transaksi yang haram zatnya tersebut diwujudkan dalam bentuk larangan memberikan pembiayaan yang terkait dengan aktivitas pengadaan jasa, produksi makanan, minuman dan bahan konsumsi lain yang diharamkan oleh Majelis Ulama Indonesia (MUI). Dalam pemberian pembiayaan, bank syatiah dituntut untuk selalu memastikan kehalalan jenis usaha yang dibantu pembiayaannya oleh bank syariah. Demikian pada suatu bank syariah tidak akan ditemui adanya pembiayaan untuk usaha yang bergerak di bidang perternakan babi, minuman keras, ataupun bisnis pornografi dan lainnya yang diharamkan.

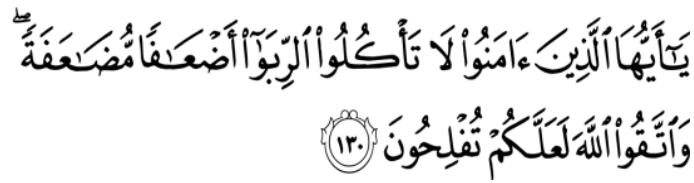

Hai orang-orang yang beriman! Janganlah kamu memakan riba dengan berlipat ganda dan bertakwalah kepada Allah agar kamu beruntung. (Al-Imran ayat 130)

Riba nasiah ialah pembayaran lebih yang disyaratkan oleh orang yang meminjamkan. Riba fadhl ialah penukaran suatu barang dengan barang yang sejenis, tetapi lebih banyak jumlahnya karena orang yang menukarkan mensyaratkan demikian, seperti penukaran emas dengan emas, padi dengan padi, dan sebagainya. Riba yang dimaksud dalam ayat ini Riba nasiah yang berlipat ganda yang umum terjadi dalam masyarakat Arab zaman jahiliyah.

\section{Metode Penelitian}

\section{Pendekatan Penelitian}

Penelitian ini menggunakan penelitian kuantitatif. Pendekatan kuantitatif merupakan suatu pendekatan yang berlandaskan pada filsafat positivisme yang digunakan untuk meneliti pada populasi atau sampel tertentu dan bersifat statistic dengan tujuan untuk menguji hipotesis yang telah ditetapkan.Model dalam penelitian ini menggunakan analisis regresi data panel sesuai dengan karakteristik data yang merupakan gabungan antara data cross section dan time series.

\section{Model Empiris}

Model empiris regresi data panel dan pemilihan variabel pada penelitian ini mengacu pada penelitian sebelumnya dengan topik serupa oleh (Chernykh \& Cole, 2011; Nasution, 2012 Rokhim \& Wulandary, 2012). Model analisis dalam penelitian sebagai berikut:

Secara umum, persamaan regresi data panel adalah sebagai berikut: $T D_{i t}=\beta_{0}+\beta_{1} c a r_{t}+\beta_{2} n p f_{i t}+\beta_{3} f d r_{i t}+\beta_{4} d i s_{i t}$

$$
+\varepsilon_{i t}
$$

$\mathrm{TD}_{\text {it }} \quad$ : Tingkat deposit bank i periode $t$. $C_{i t}$ : Capital Adequacy Ratio (CAR) bank i periode $\dagger$

$f d r_{i t}$ : Financing to Deposit Ratio (FDR) bank i periode $\dagger$ 
Luliansari, et al/Jurnal Ekonomi Syariah Teori dan Terapan Vol. 6 No. 12 Desember 2019: 2451-2470; FAKTOR-FAKTOR YANG MEMPENGARUH TERHADAP TINGKAT DEPOSIT BANK UMUM SYARIAH PERIODE 2011-2018

$n p f_{i t} \quad$ : Non performing Financing (NPF) bank i periode $\dagger$

DISit :Deposit Insurance system bank i pada periode $\dagger$

Eit : Koefisien Error

\section{Definisi Operasional}

1. Tingkat Deposit

Jika bank menghimpun deposit lebih banyak, maka dana yang disalurkan kepada masyarakat dalam bentuk kredit jumlahnya akan lebih besar. Besarnya deposit suatu bank dipengaruhi oleh berbagai macam faktor. Penelitian Chernykh dan Cole (2010) membuktikan bahwa bank yang menjadi anggota penjaminan simpanan menghimpun deposit dari masyarakat dengan jumlah yang lebih besar, sedangkan bank yang tidak menjadi anggota penjaminan simpanan menghimpun deposit dalam jumlah yang lebih sedikit. Permodalan juga menjadi faktor yang mempengaruhi tingkat deposit suatu bank.

Hasil penelitian Vale (2011), menunjukkan bahwa kenaikan jumlah modal bank akan menurunkan risiko kredit sehingga meningkatkan kepercayaan masyarakat untuk menyimpan dananya di bank tersebut. Merujuk kepada Chernykh dan Cole (2010), total deposit pada bank diperoleh dari akun dana pihak ketiga (DPK) di sisi pasiva laporan neraca bank (i) pada periode (t). DPK dibedakan antara bank umum dan bank umum syariah. DPK pada bank umum diambil dari akun giro, tabungan, serta deposito. Khusus bank syariah, DPK terdiri dari dana simpanan wadiah (terdiri dari giro wadiah dan tabungan wadiah) dan juga dana investasi tidak terikat atau disebut dengan mudharabah muthlaqah, yang terdiri dari tabungan mudharabah dan deposito mudharabah.

$$
\begin{aligned}
\text { Deposit_Asset }= & \frac{\text { Total Dana Pihak Ketiga }}{\text { Total Asset }} \\
& \times 100 \%
\end{aligned}
$$

2. CAR

Capital Adequacy Ratioadalah modal berbandingan aktiva yang mengandung risiko atau rasio kecukupan modal minimum dengan memperhitungkan risiko pasar (market risk). Berdasarkan ketentutan PBI No. 10/26/PBI/2008 tentang Fasilitas Pendanan Jangka Pendek Bagi Bank Umum, minimum CAR bagi Bank Umum adalah sebesar 8\%, ketentuan itu mengacu kepada ketentuan BASEI II. Penyediaan modal minimum menurut $B A B 1$ pasal 2 ayat 1-3 No. 15/12/PBI/2013 tentang Kewajiban Penyedian Modal Minimum Bank Umum ditetapkan paling rendah sebagai berikut:

a. 8\% (delapan persen) dari Aset Tertimbang Menurut Risiko (ATMR) untuk Bank dengan profil risiko peringkat 1 (satu);

b. $9 \%$ (sembilan persen) sampai dengan kurang dari 10\% (sepuluh persen) dari ATMR untuk Bank dengan profil risiko peringkat 2 (dua);

c. $10 \%$ (sepuluh persen) sampai dengan kurang dari $11 \%$ (sebelas persen) dari ATMR untuk Bank 
dengan profil risiko peringkat 3 (tiga); atau

d. $11 \%$ (sebelas persen) sampai dengan $14 \%$ (empat belas persen) dari ATMR untuk Bank dengan profil risiko peringkat 4 (empat) atau peringkat 5 (lima).

CAR menunjukkan seberapa besar modal bank untuk menunjang kebutuhannya dan semakin besar CAR maka akan semakin besar daya tahan bank yang bersangkutan dan menunjukkan semakin sehat bank tersebut. Menurut Dumicic dan Ridzak, Capital Adequacy Ratio merupakan proksi yang digunakan untuk menilai creditworthiness suatu bank. Capital Adequacy Ratio digunakan oleh regulator untuk mencegah bank melakukan aktivitas yang berisiko. Tujuan regulasi adalah demi menjaga stabilitas sistem perbankan (Claeys dan Vennet, 2008).

$$
C A R=\frac{\text { Capital }}{R W A / A T M R(\text { tagihan } \times \text { bobot resiko })}
$$

3. NPF

Rasio yang digunakan bank syariah untuk mengukur risiko pembiayaan bermasalah dikenal dengan Non Performing Finance (NPF). Non Performing Finance (NPF) atau pembiayaan bermasalah merupakan salah satu indicator kunci untuk menilai kinerja bank. Pembiayaan bermasalah adalah pembiayaan yang pembayaran angsuran pokok dan/atau bungnya telah lewat 90 hari setelah jatuh tempo atau pembiayaan yang pembayarannya secara tepat waktu sangat diragukan.
NPF seacara luas didefinisikan sebagai suatu pembiayaan dimana pembayaran yang dilakukan tersendat-sendat dan tidak mencukupi kewajiban minimal yang ditetapkan sampai dengan pembiayaan yang sulit untuk dilunasi atau bahkan tidak dapat ditagih. Dalam peraturan Bank Indonesia tentang Penilaian Kualitas Bank Umum yang melaksanakan kegiatan usaha berdasarkan prinsip syariah pasal 9 ayat (2) menyatakan kualitas produktifitas dalam bentuk pembiayaan dibagi dalam 5 golongan yaitu lancar (L), dalam perhatian khusus (DPK), kurang lancer (KL), diraguakan (D), Macet (M).

Risiko pembiayaan bagi bank syariah timbul apabila kualitas pembiayaan dari lancar menjadi kurang lancar, diragukan dan macet atau dalam praktik disebut pembiayaan bermasalah atau non perfoming financing (NPF). Hasil penelitian Vale (2011), menunjukkan bahwa kenaikan jumlah modal bank akan menurunkan risiko kredit sehingga meningkatkan kepercayaan masyarakat untuk menyimpan dananya di bank tersebut. Deposan juga melihat risiko kredit suatu bank melalui besaran NPL bank tersebut. NPL yang tinggi menjadi salah satu indikasi bahwa bank memiliki masalah dengan kreditnya. Semakin tinggi NPL, berpengaruh terhadap tingkat deposit secara negatif (Tsuru, 2003). Peraturan Bank Indonesia Kelembagaan Penilai Tingkat Kesehatan Bank, tahun 2012 Besarnya rasio NPF yang diperoleh Bank Indonesia adalah maksimal 5\% jika 
Luliansari, et al/Jurnal Ekonomi Syariah Teori dan Terapan Vol. 6 No. 12 Desember 2019: 2451-2470; FAKTOR-FAKTOR YANG MEMPENGARUH TERHADAP TINGKAT DEPOSIT BANK UMUM SYARIAH PERIODE 2011-2018

melebihi angka 5\% maka akan anggota penjaminan simpanan mempengaruhi penilaian tingkat kesehatan bank yang bersangkutan.

Rasio NPF $=\frac{\text { Pembiayaan }(K L, D, M)}{\text { Total Pembiayaan }} \times 100 \%$

4. DIS

Wheelock dan Kumbhakar (1995), dalam penelitiannya terhadap pelaksanaan deposit insurance di Kansas pada tahun 1910 menemukan bahwa bank melakukan perilaku moral hazard diukur dari penurunan rasio kecukupan modal. Dari sisi regulasi, BI sebagai regulator yang berwenang melakukan fungsi pengawasan terhadap perbankan hingga 31 Desember 2013 berupaya menjaga kestabilan sistem perbankan dengan cara menerapkan berbagai macam regulasi. Salah satunya adalah dengan melakukan pembinaan dan pengawasan bank dengan menetapkan ketentuan tentang kesehatan bank, yang memperhatikan aspek permodalan, kualitas aset, kualitas manajemen, rentabilitas, likuiditas dan solvabilitas serta aspek lain yang berhubungan dengan usaha bank (CAMELS).

Berkaitan dengan hal tersebut, BI juga secara perlahan mengimplementasikan Basel II. Besarnya deposit dapat dipengaruhi bank yang sudah menjadi bagian dari deposit insurance. Penelitian Chernykh dan Cole (2010) membuktikan bahwa bank yang menjadi anggota penjaminan simpanan menghimpun deposit dari masyarakat dengan jumlah yang lebih besar, sedangkan bank yang tidak menjadi menghimpun deposit dalam jumlah yang lebih sedikit. Permodalan juga menjadi faktor yang mempengaruhi tingkat deposit suatu bank.

Berkaitan dengan perannya dalam perekonomian, industri perbankan di Indonesia memegang peranan yang sangat penting. Stabilitas perbankan merupakan sesuatu yang diperhatikan oleh pemerintah. Bank Indonesia (BI) sebagai bank sentral, Lembaga Penjamin Simpanan (LPS) dan Otoritas Jasa Keuangan (OJK) berupaya menjaga stabilitas perbankan melalui regulasi seperti kebijakan rasio kecukupan modal (CAR), batas maksimum non performing loan (NPL) dan kewajiban menjadi anggota penjaminan simpanan. Dalam penelitian Chernykh dan Cole (2010) semakin lama bank bergabung dengan deposit insurance system semakin besar tingkat deposito dan rasio simpanan terhadap asset. Karena dalam penelitian tersebut bertujuan melihat respon lamanya bank-bank yang telah bergabung ke deposit insurance setalah kebijakan deposit insurance diterapkan di negara Rusia. Demikian dalam penelitiannya peneliti mengukur deposit insurance system dengan lamanya bank bergabung dengan deposit insurance.

\section{Jenis dan Sumber Data}

Jenis data yang digunakan dalam penelitian adalah data kuantitaf yakni data berupa angka-angka atau data data kualitatif yang diangkakan. Data 
Luliansari, et al/Jurnal Ekonomi Syariah Teori dan Terapan Vol. 6 No. 12 Desember 2019: 2451-2470; FAKTOR-FAKTOR YANG MEMPENGARUH TERHADAP TINGKAT DEPOSIT BANK UMUM SYARIAH PERIODE 2011-2018

yang digunakan dalam penelitian ini adalah data sekunder, yang berasal dari laporan keuangan tahun yang disediakan oleh bank dan lembaga lain pada periode 2010-2018. Data diambil dari website www.bi.go.id atau www.ojk.go.id dan laporan tahunan setiap bank umum syariah.

\section{Prosedur Pengelolaan Data}

Pengumpulan data dalam penelitian ini memiliki beberapa prosedur diantaranya:

1. Studi Kepustakaan berupa kajian literatur mengenai topik penelitian dari berbagai sumber utama seperti artikelartikel ilmiah yang terpublikasi pada jurnal terindeks scopus, artikel jurnal pendukung lainnya dan buku yang berkaitan dengan penjelasan topik penelitian. Literatur-literatur tersebut dikumpulkan dan beberapa dijadikan acuan penulis dalam penentuan model analisis dan pertimbangan dalam pemilihan variabel-variabel penelitian yang dikelompokkan sebagai penelitian terdahulu dan sebagian lagi digunakan sebagai tambahan penjelasan yang dibutuhkan dalam penelitian ini.

2. Dokumentasi berupa pengumpulan data-data sekunder yang dibutuhkan dalam penelitian dari berbagai website resmi institusi pemerintah yang berwenang menyajikan data laporan publikasi keuangan pada Bank Umum Syariah dan informasi mengenai deposit insurance.

\section{Populasi dan Sampel}

Populasi merupakan wilayah generalisasi yang terjadi atas subyek yang mempunyai kualitas dan karakteristik tertentu yang ditetapkan oleh penulis untuk dipelajari dan kemudian ditarik kesimpulan (Anshori \& Iswati, 2009:92). Sedangkan sampel merupakan bagian dari jumlah dan karakteristik yang di miliki oleh populasi (Anshori \& Iswati, 2009:94). Berdasarkan ulasan tersebut, populasi dalam penelitian ini adalah seluruh industri perbankan syariah yang ada di Indonesia. Pemilihan sampel dalam penelitian ini menggunakan metode purposive sampling yaitu metode pengambilan sampel dengan kriteria atau batasanbatasan tertentu dengan tujuan untuk mendapatkan data-data yang memiliki kesesuaian dengan tujuan penelitian. Penentuan kedua bank ini didasari oleh beberapa pertimbangan diantaranya:

1. Bank yang terdaftar dalam Otoritas Jasa Keuangan.

2. Memiliki laporan keuangan dari tahun 2001-2018.

Penelitian ini menggunakan 11 sampel bank umum syariah sebagai berikut:

Tabel 1.

Daftar Bank Umum Syariah yang Memenuhi Kriteria Sampel

\begin{tabular}{|c|l|}
\hline No & \multicolumn{1}{|c|}{ Nama Bank } \\
\hline 1 & Bank Muamalat Indonesia \\
\hline 2 & Bank Syariah Mandiri \\
\hline 3 & Bank Mega Syariah \\
\hline 4 & Bank BRI Syariah \\
\hline 5 & Bank Syariah Bukopin \\
\hline
\end{tabular}


Luliansari, et al/Jurnal Ekonomi Syariah Teori dan Terapan Vol. 6 No. 12 Desember 2019: 2451-2470; FAKTOR-FAKTOR YANG MEMPENGARUH TERHADAP TINGKAT DEPOSIT BANK UMUM SYARIAH PERIODE 2011-2018

\begin{tabular}{|c|l|}
\hline 6 & Bank Panin Dubai Syariah \\
\hline 7 & Bank BNI Syariah \\
\hline 8 & Bank Victoria Syariah \\
\hline 9 & Bank BJB Syariah \\
\hline 10 & Bank Maybank Syariah \\
\hline 11 & Bank BCA Syariah \\
\hline
\end{tabular}

Teknik Analisis

Teknik analisis dalam penelitian ini menggunakan analisis regresi data panel karena data yang digunakan dalam penelitian ini merupakan gabungan dari data cross section dan data time series. Seperti yang sudah dijelaskan pada bagian sebelumnya, data dikumpulkan mulai dari tahun 2010 sampai dengan tahun 2018. Berikut penjelasan lebih lanjut terkait dengan bagian-bagian dalam teknik analisis yang digunakan dalam penelitian ini sebagai berikut:

\section{Regresi Data Panel}

Regresi data panel adalah gabungan antara data cross section dan data time series, dimana unit cross section yang sama diukur pada waktu berbeda (Baltagi, 2001). Dengan kata lain, data panel merupakan data dari beberapa individu sama yang diamati dalam kurun waktu tertentu. Jika memiliki data T periode waktu $(\dagger=1,2, \ldots, \mathrm{T})$ dan $\mathrm{N}$ jumlah individu $(i=1,2, \ldots, N)$, maka dengan data panel terdapat total unit observasi sebanyak NT. Jika jumlah unit waktu sama untuk setiap individu, maka data disebut balanced panel. Jika sebaliknya, yakni jumlah unit waktu berbeda untuk setiap individu, maka disebut unbalanced panel. Berdasarkan

penjelasan tersebut, penelitian ini tergolong sebagai balanced panel karena periode waktu digunakan dalam setiap sampel sama yakni 9 tahun.

\section{Persamaan Regresi Data Panel}

Persamaan Regresi data panel ada dua macam, yaitu One Way Model dan Two Way Model.One Way Model adalah model satu arah, karena hanya mempertimbangkan efek individu (ai) dalam model seperti yang di tunjukkan dalam persamaan berikut:

Model One Way Data Panel

Yit $=a+a i+x i t \beta+\varepsilon i t$

Dimana:

$a=$ Konstanta

$\beta=$ Vektor berukuran $\mathrm{P} \times 1$ merupakan parameter hasil estimasi

$X_{i t}=$ Observasi ke-it dari $P$ variabel bebas

$a_{i}=$ efek individu yang berbeda-beda untuk setiap individu ke-i

$\varepsilon_{i t}=$ error regresi seperti halnya pada model regresi klasik

Two Way Model adalah model yang mempertimbangkan efek dari waktu atau memasukkan variabel waktu. Berikut Persamaannya:

Model Two Way Data Panel

$$
Y_{i t}=a+a_{i}+\delta_{\dagger}+x_{i t} \beta+\varepsilon_{i t}
$$

Persamaan di atas menunjukkan, terdapat tambahan efek waktu yang dilambangkan dengan deltha $\left(\delta_{t}\right)$ yang dapat bersifat tetap ataupun bersifat acak antar tahunnya. 


\section{Asumsi Regresi Data Panel}

Uji asumsi klasik tidak diperlukan dalam analisis data panel karena data panel dapat meminimlakan bias yang kemungkinan besar muncul dalam hasil analisis, memberi lebih banyak informasi, variasi, dan degree of freedom (Gujarati, 2012:237). Keunggulan-keunggulan data panel menyebabkan data panel mampu mendeteksi dan mengukur dampak dengan lebih baik dimana hal ini tidak bisa dilakukan dengan metode cross section maupun time series. Panel data memungkinkan mempelajari lebih kompleks mengenai prilaku yang ada dalam model sehingga pengujian data panel tidak memerlukan uji asumsi klasik (Gujarati 1992 dalam Iswanto (2013)).

\section{Kelebihan dan kekurangan Data Panel}

Baltagi (2008) mengemukakan beberapa kelebihan dari data panel yaitu:

1. Membantu mengendalikan heterogenity setiap individu yang digunakan dalam pengamatan.

2. Memberikan data yang lebih informatif, bervariasi, koleniaritas yang lebih rendah, derajat kebebasan dan efisiensi yang lebih tinggi dibandingkan dengan data time series dan cross section.

3. Data panel menawarkan studi mengenai dinamika suatu perubahan dengan lebih baik. Berbeda dengan data cross section yang tidak dapat menunjukkan perubahan suatu variabel dalam setiap periode pengamatan karena seluruh data ditarik pada satu titik waktu tertentu.

4. Data panel memungkinkan untuk mengidentifikasi dan mengukur pengaruh yang tidak dapat dilakukan dengan menggunakan time series maupun cross section.

5. Data panel memungkinkan studi dan pengujian dengan model yang kompleks, dan beberapa kelebihan lainnya.

Data panel juga memiliki keterbatasan yaitu:

1. Permasalahan dalam memperoleh data atau informasi setiap individu dan referensi yang dapat digunakan untuk menentukan periode pengamatan ( $\mathrm{t}$ ) yang akan digunakan.

2. Bisa menimbulkan distorsi akibat kesalahan pengukuran.

3. Selectivity problem yang dibedakan atas self selectivity (kesalahan memilih data), non-response (sebagian atau seluruh pertanyaan tidak terjawab), dan attrition (data yang dikumpulkan tidak lengkap karena responden menghilang, pindah, atau meninggal).

4. Dimensi waktu yang pendek.

5. Cross sectional dependence yang bisa menimbulkan misleading inference karena tidak mempertimbangkan adanya keterkaitan antara individu.

\section{HASIL DAN PEMBAHASAN}

\section{Statistika Deskriptif}

Analisis statistic deskriptif dalam penelitian ini bertujuan untuk menjelaskan gambaran mengenai variabel-variabel 
Luliansari, et al/Jurnal Ekonomi Syariah Teori dan Terapan Vol. 6 No. 12 Desember 2019: 2451-2470; FAKTOR-FAKTOR YANG MEMPENGARUH TERHADAP TINGKAT DEPOSIT BANK UMUM SYARIAH PERIODE 2011-2018

yang digunakan dalam penelitian ini, yaitu Tingkat deposit, CAR, NPF dan DIS. Deskripsi variabel tersebut meliputi nilai rata-rata (mean), niali maksimum, nilai minimum dan standar deviasi.

Tabel 2.

\section{Statistik Deskriptif}

\begin{tabular}{|l|r|r|r|r|}
\hline & mean & Min. & Maks. & $\begin{array}{l}\text { Standar } \\
\text { Deviasi }\end{array}$ \\
\hline $\begin{array}{l}\text { Tingkat } \\
\text { deposit }\end{array}$ & 0.53 & 0.05 & 0.90 & 0.26 \\
\hline CAR & 0.73 & 11.1 & 83.07 & 27.77 \\
\hline NPF & 2.29 & 0.04 & 9.8 & 24.87 \\
\hline DIS & 10.82 & 8 & 18 & 14.33 \\
\hline
\end{tabular}

Sumber: Olahan penulis (2019)

\section{Pemilihan Model Regresi Data Panel}

Penelitian ini menggunakan analisis regresi linier data panel untuk mengetahui pengaruh variabel eksogen yaitu Capital Adequacy Ratio (CAR),Non Performing Finance (NPF) dan Deposit Insurance System terhadap variabel endogen yaitu tingkat deposit pada Bank Umum Syariah. Ada tiga pendekatan yang digunakan dalam mengestimasi model regresi data panel antara lain Commond Effect Model (CEM), Fixed Effect Model (FEM), dan Random Effect Model (REM). Untuk menghasilkan metode yang terbaik maka dilakukan beberapa uji yaitu Uji Chow dan Uji Hausman. Uji Chow digunakan untuk memilih model terbaik antara Commond Effect Model (CEM) atau Fixed Effect Model (FEM) sedangkan Uji Hausman digunakan untuk memilih model terbaik antara Fixed Effect Model (FEM) atau Random Effect Model (REM).

Uji Chow dilakukan untuk memilih model terbaik antara Common Effect
Model (CEM) atau Fixed Effect Model (FEM). Hipotesis dari uji chow adalah sebagai berikut:

HO: menggunakan model Common Effect Model (CEM)

$\mathrm{HI}$ : menggunakan model Fixed Effect Model (FEM)

Perolehan hasil setelah melakukan pengujian dengan uji chow, sebagai berikut:

Tabel 3.

Hasil Uji Chow

\begin{tabular}{|c|c|c|c|}
\hline $\begin{array}{c}\text { Effect } \\
\text { Test }\end{array}$ & Statistic & D.f & Prob. \\
\hline $\begin{array}{c}\text { Cross- } \\
\text { section } \mathrm{F}\end{array}$ & 12.518197 & $(10,74)$ & 0,0000 \\
\hline
\end{tabular}

Sumber: Data diolah, 2019

Tabel 3 menunjukkan bahwa perolehan nilai probabilitas /Cross-section F) sebesar 0,0000 lebih kecil dari 0,05 atau $5 \%$ sehingga HO ditolak. Dapat disimpulkan bahwa model terbaik yang digunakan antara Fixed effect Model (FEM) atau Common Effect Model (CEM) dalam penelitian ini adalah Fixed Effect Model (FEM).

Uji Hausman dilakukan untuk menentukan model terbaik antara Fixed Effect Model (FEM) atau Random Effect Model (REM). Hipotesis yang digunakan dalam Uji Hausman sebagai berikut: HO: menggunakan model Random Effect Model (REM)

$\mathrm{H} 1$ : menggunakan model Fixed Effect Model (FEM)

Perolehan hasil setelah melakukan pengujian dengan uji Hausman, sebagai berikut: 
Luliansari, et al/Jurnal Ekonomi Syariah Teori dan Terapan Vol. 6 No. 12 Desember 2019: 2451-2470; FAKTOR-FAKTOR YANG MEMPENGARUH TERHADAP TINGKAT DEPOSIT BANK UMUM SYARIAH PERIODE 2011-2018

Tabel 4.

Hasil Uji Hausman

\begin{tabular}{|c|c|c|c|}
\hline $\begin{array}{c}\text { Test } \\
\text { Summary }\end{array}$ & $\begin{array}{c}\text { Chi-Sq. } \\
\text { Statistic }\end{array}$ & $\begin{array}{c}\text { Chi- } \\
\text { Sq. } \\
D, f\end{array}$ & Prob. \\
\hline $\begin{array}{c}\text { Cross- } \\
\text { section } \\
\text { random }\end{array}$ & 36.058366 & 3 & 0,0000 \\
\hline
\end{tabular}

Sumber: data diolah, 2019

Tabel 4 menunjukkan bahwa perolehan nilai probabilitas (Cross-section random) sebesar 0,0000 lebih besar dari 0,05 atau $5 \%$ sehingga $\mathrm{HO}$ ditolak. Dapat disimpulkan bahwa model terbaik yang digunakan antara Fixed effect Model (FEM) atau Random Effect Model (REM) dalam penelitian ini adalah Fixed effect Model (FEM). Kedua uji yang telah penulis lakukan memberikan kesimpulan bahwa model terbaik yang dapat digunakan dalam penelitian ini adalah Fixed effect Model (FEM).

\section{Kooefisien Determinasi $\mathbf{R}^{2}$}

Koofisien Determinasi $\mathrm{R}^{2}$ dilakukan untuk melihat seberapa jauh kemampuan variabel eksogen dalam menjelaskan variabel endogen. Nilai Koefisien determinasi adalah $0<\mathrm{R}$ squared $<1$. Apabila nilai koefisien determinasi semakin mendekati 1 maka dianggap semakin baik karena variabel independen yang digunakan mampu menjelaskan variabel dependen. Berikut adalah hasil uji koofisien determinasi $\mathrm{R}^{2}$ dengan model terbaik Random Effect Model:

Tabel 5.

Hasil Koofisien Determinasi $\mathbf{R}^{\mathbf{2}}$

\begin{tabular}{|c|c|}
\hline R-squared & 0,752711 \\
\hline Adjusted R-Squared & 0,709268 \\
\hline
\end{tabular}

Berdasarkan tabel 5 di atas nilai Rsquared sebesar 0,752711 atau $75,2 \%$. Dapat disimpulkan bahwa variabel Capital Adequacy Ratio (CAR), Financing to Deposit Ratio (FDR), Non performing Financing (NPF) dan Deposit Insurance system (DIS) dapat menjelaskan 70,92\%. dari variabel Tingkat Deposit pada Bank Umum Syariah pada periode 201 1-2018.

\section{Uji Hipotesis}

1. Uji Statistik F

Uji statistik $F$ dilaukan untuk mengetahui apakah semua variabel independen yang dimasukkan dalam model regresi memberikan pengaruh signifikan secara simultan/bersama-sama terhadap variabel dependen (Ghozali 2011:98). Hipotesis dari uji ini adalah sebagai berikut:

$H_{0}: \beta_{1}=\beta_{2}=\beta_{3}=\beta_{4}=0$, artinya semua variabel independen memberikan pengaruh signifikan secara simultan/bersama-sama terhadap variabel dependen

$H_{1}$ : minimal ada $1 \beta \neq 0$, artinya setidaknya ada satu variabel independen yang memberikan pengaruh signifikan secara simultan terhadap variabel depeden.

Hipotesis satu diterima apabila nilai probabilitas $<0,05$ atau $5 \%$ maka variabel independen memberikan pengaruh signifikan secara simultan terhadap variabel dependen, sedangkan hipotesis satu ditolak apabila nilai probabilitas > 0,05 atau $5 \%$ maka variabel independen tidak memberikan pengaruh signifikan secara simultan terhadap variabel 
Luliansari, et al/Jurnal Ekonomi Syariah Teori dan Terapan Vol. 6 No. 12 Desember 2019: 2451-2470; FAKTOR-FAKTOR YANG MEMPENGARUH TERHADAP TINGKAT DEPOSIT BANK UMUM SYARIAH PERIODE 2011-2018

dependen. Berikut adalah hasil uji $F$ statistik sebagai berikut:

Tabel 6.

Hasil Uji F Statistik

\begin{tabular}{|c|c|}
\hline F-statistic & 17.32654 \\
\hline Prob (F-Statistic) & 0,00000 \\
\hline
\end{tabular}

Sumber: data diolah, 2019

Hasil uji F statistik yang ditunjukkan pada tabel 4.10 merupakan hasil uji $F$ pada model terbaik yaitu Fixed effect Model (FEM). Nilai dari probabilitas yang ditunjukkan pada tabel Prob(F-statistic) sebesar 0,000000 yang berarti nilainya kurang dari tingkat signifikan 0,05 atau $5 \%$. Apabila nilai probabilitas kurang dari 0,05 atau $5 \%$ maka $\mathrm{HO}$ ditolak dan diterimanya H1. Dapat disimpulkan bahwa variabel Capital Adequacy Ratio (CAR), Financing to Deposit Ratio (FDR), Non performing Financing (NPF) dan Deposit Insurance system (DIS) secara simultan berpengaruh signifikan terhadap Tingkat Deposit.

2. Uji T Parsial

Uji T Parsial pada dasarnya menunjukkan seberapa jauh pengaruh satu variabel penjelas atau independen secara individual dalam menerangkan variabel dependen (Ghozali,2011:98). Hipotesis dari uji ini adalah sebagai berikut:

$H_{0}: \beta_{1}=0$, artinya satu variabel independen secara parsial tidak memberikan pengaruh signifikan terhadap variabel dependen.

$H_{1}: \beta \neq 0$, artinya satu variabel independen secara parsial memberikan pengaruh signifikan terhadap variabel dependen.

Hipotesis satu diterima apabila nilai probabilitas (t-stat) $<0,05$ atau $5 \%$ maka variabel independen memberikan pengaruh signifikan secara parsial terhadap variabel dependen, sedangkan hipotesis satu ditolak apabila nilai probabilitas (t-stat)> 0,05 atau 5\% maka variabel independen tidak memberikan pengaruh signifikan terhadap variabel dependen. Berikut adalah hasil dari Uji T parsial sebagai berikut:

Tabel 7.

Hasil Uji T Parsial

\begin{tabular}{crrrr}
\hline \hline Variable & Coefficient & Std. Error & t-Statistic & Prob. \\
\hline \hline C & 0.480448 & 0.166014 & 2.894028 & 0.0050 \\
CAR & 0.094705 & 0.039756 & 2.382132 & 0.0198 \\
NPF & 0.058506 & 0.021210 & 2.758382 & 0.0073 \\
DIS & -0.025301 & 0.018840 & -1.342968 & 0.1834 \\
\hline \hline
\end{tabular}

Sumber: Data diolah 2019

Berdasarkan Tabel 7, kesimpulan yang dapat dapat diambil adalah sebagai berikut:

1. Nilai uji $\dagger$ variabel Capital Adequacy Ratio (CAR) sebesar 0,0198. Nilai ini lebih kecil dari nilai signifikan yaitu 0,05 atau $5 \%$, sehingga $\mathrm{HO}$ ditolak dan $\mathrm{HI}$ diterima. Hal ini menunjukkan bahwa variabel CAR berpengaruh signifikan terhadap Tingkat Deposit. Nilai koofisien dari CAR sebesar 0,094705 berarti setiap variabel CAR mengalami kenaikan satu satuan, sedangkan variabel lainnya dianggap konstan maka tingkat deposit mengalami peningkatan sebesar 0,094705. Dapat disimpulkan bahwa variabel CAR berpengaruh positif signifikan terhadap tingkat deposit.

2. Nilai uji $\dagger$ variabel Non Performing Finance (NPF) sebesar 0,0073. Nilai ini lebih kecil dari nilai signifikan yaitu 0,05 
atau $5 \%$, sehingga $\mathrm{HO}$ ditolak dan $\mathrm{Hl}$ diterima. Hal ini menunjukkan bahwa variabel NPF berpengaruh signifikan terhadap Tingkat Deposit. Nilai koofisien dari NPF sebesar 0,058506 berarti setiap variabel mengalami kenaikan satu satuan, sedangkan variabel lainnya dianggap konstan maka tingkat deposit mengalami peningkatan sebesar 0,058506. Dapat disimpulkan bahwa variabel NPF berpengaruh positif signifikan terhadap tingkat deposit.

3. Nilai uji $\dagger$ variabel Deposit Insurance System sebesar 0,1834 Nilai ini lebih besar dari nilai signifikan yaitu 0,05 atau $5 \%$, sehingga $\mathrm{HO}$ diterima dan $\mathrm{Hl}$ ditolak. Hal ini menunjukkan bahwa variabel Deposit Insurance System tidak berpengaruh terhadap Tingkat Deposit. Nilai koofisien dari Deposit Insurance System sebesar $-0,025301$ berarti setiap variabel Deposit Insurance System mengalami kenaikan satu satuan maka tingkat deposit mengalami peningkatan sebesar $-0,025301$. Dapat disimpulkan bahwa Deposit Insurance System tidak berpengaruh negatif signifikan terhadap tingkat deposit.

\section{Interpretasi Hasil dan Pembahasan}

1. Pengaruh CAR terhadap tingkat deposit Capital Adequacy Ratio (CAR) berpengaruh positif signifikan terhadap tingkat deposit Bank Umum Syariah di Indonesia periode 2010-2019. Berdasarkan olahan data statistik hasil uji hipotesis $\dagger$ pada tabel 4.11 yang menujukkan bahwa analisis dengan uji $\dagger$ siginifikan positif sebesar 0.0495 lebih kecil dari 0.05, maka $\mathrm{HO}$ ditolak dan $\mathrm{HI}$ diterima. Hasil dari penelitian sejalan dengan Rokhim dan Wulandary (2012) dan Penelitian Sofyan, Idqan dan Irfan (2017) CAR berpengaruh terhadap tingkat deposit. CAR berpengaruh terhadap tingkat deposit semakin besar variabel CAR, perbankan berani untuk menghimpun dana dari masyarakat karena kecukupan modal untuk mengcover kerugian jika terjadi kejatuhan bank (Siamat, 2005). Capital Adequacy Ratio menunjukkan beberapa diantaranya melihat respon bank terhadap risiko. Pada saat tingkat permodalan rendah dengan demikian bank tersebut lebih berisiko, sebaliknya jika rasio kecukupan tinggi maka bank menjadi lebih aman di bandingkan dengan bank lain yang memiliki rasio kecukupan lebih sedikit.

Penemuan dari penelitian Vale (2011 yakni rasio kecukupan modal meningkat akan menurutkan risiko kredit yang berdampak pada meningkatnya kepercayaan masyarakat untuk menyimpan dananya di bank tersebut. Tingginya nilai CAR dapat menambah keprcayaan masyarakat terhadap bank, karena bank telah menyediakan cadangan modal yang lebih besar untuk mecegah dari default.

Ketentuan kewajiban penyedia modal minimum yang dilakukan oleh bank Indonesia melalui PBI No. 10/15/PBI /2008 baru mencapai implementasi Basel ॥ 
Luliansari, et al/Jurnal Ekonomi Syariah Teori dan Terapan Vol. 6 No. 12 Desember 2019: 2451-2470; FAKTOR-FAKTOR YANG MEMPENGARUH TERHADAP TINGKAT DEPOSIT BANK UMUM SYARIAH PERIODE 2011-2018

secara utuh. Perhitungan penyedia modal wajib di dasarkan pada risiko pasar (per tahun 2007), risiko operasional (per tahun 2001) dan risiko kredit (per tahun 2012) Implementasi cenderung masih fokus hanya kepada profil risiko dan belum memperhitungkan kualitas dari permodalan itu sendiri. hal inilah yang diakomodasi oleh basel III yang akan seacara penuh diterapakan.

2. Pengaruh NPF terhadap tingkat deposit Non Performing Financing berpengaruh signifikan dan bernilai positif terhadap tingkat deposito bank umum syariah. hasil ini sejalan dengan penelitan dari Irfan, dkk. Hasil tersebut menunjukkan kemampua manajemen bank dalam mengelolah kredit bermasalah yang diberikan bank dengan hasil yang positif mengindikasikan bank mampu menutupi pembiayaan bermasalah dengan tingkat deposit yang telah terkumpulkan (Setiawan, 2009). Hasil penelitian Vale (2011), menunjukkan bahwa kenaikan jumlah modal bank akan menurunkan risiko kredit sehingga meningkatkan kepercayaan masyarakat untuk menyimpan dananya di bank tersebut.

Deposan juga melihat risiko kredit suatu bank melalui besaran NPL bank tersebut. NPL yang tinggi menjadi salah satu indikasi bahwa bank memiliki masalah dengan kreditnya. Semakin tinggi NPL, berpengaruh terhadap tingkat deposit secara negatif (Tsuru, 2003).Dendawijaya mengemukakan, salah satu dampak dari keberadaan NPF yang tidak wajar adalah hilangnya kesempatan memperoleh income (pendapatan) dari pembiayaan yang diberikan, sehingga mempengaruhi perolehan laba dan akan berpengaruh terhadap tingkat bagi hasil yang diberikan kepada nasabah. Sebaliknya, ketika NPF suatu bank berada pada posisi wajar atau rendah, maka keuntungan yang diperoleh bank dari pembiayaan yang diberikan akan semakin besar dan akan meningkatkan porsi bagi hasil yang akan dibagikan kepada nasabah.

Menurut penelitian Barajas dan Steiner (2000) menemukan bahwa perilaku deposa dalam menyimpan dana di bank dipengaruhi oleh variabel fundamental sebuah bank. Melihat pada study case industry thrift di Amerika Serika pada periode 1980-an, Park dan Peristiani (1998) menemukan ketika bank terlibat aktivitas berisiko maka deposa meminta menaikkan bunga deposito.

Namun hasil yang di temukan oleh Tsuru (2003) dengan objek penlitian di Jepang yakni temuan adalah variabel Non Performing Finance terbukti mempengaruhi tingkat deposit secara negatif, karena masyarakat menyadari keberadaan Non Performing Finance jika nilainya tinggi maka akan menurunkan kepercayaan masyarakat dan jumlah simpanan pun akan turun. Hasil penelitian Rahmat (2012) membuktikan bahwa semakin tinggi nilai NPF maka tingkat profitabilitas semakin rendah, sedangkan semakin rendah nilai NPF akan 
Luliansari, et al/Jurnal Ekonomi Syariah Teori dan Terapan Vol. 6 No. 12 Desember 2019: 2451-2470; FAKTOR-FAKTOR YANG MEMPENGARUH TERHADAP TINGKAT DEPOSIT BANK UMUM SYARIAH PERIODE 2011-2018

meningkatkan profitabilitas atau keuntungan yang diperoleh bank syariah. Meningkatnya profitabilitas atau keuntungan yang diperoleh bank syariah tentunya akan mempengaruhi tingkat bagi hasil yang diberikan bank kepada nasabah.

3. Pengaruh DIS terhadao tingkat deposit

Chernykh dan Cole (2011) menemukan bahwa keanggotaan bank dalam sistem asuransi simpanan mempengaruhi kemampuan bank untuk mengumpulkan dana (deposit). Faktor lain yang berpengaruh terhadap asuransi simpanan adalah modal, peningkatan modal akan mengurangi risiko kredit oleh karena itu, ini akan meningkatkan kepercayaan publik untuk menyimpan vang mereka di bank (Vale, 2011).

DIS tidak berpengaruh signifikan terhadap tingkat deposit hal ini berkebalikan dengan hasil penelitian Chernykh dan Cole (2010) di Rusia yaitu semakin lama suatu bank menjadi anggota penjamin simpanan maka berdampak positif terhadap deposit taking bank tersebut. Namun Sejalan dengan hasil penelitian Wulandary (2013) penjaminan simpanan tidak berpengaruh siginfikan terhadap tingkat deposit dikarenakan fenomena yang terjadi di indonesia kebijakan penjaminan simpanan diwajibkan untuk semua bank umum baik konvensional maupun syariah yang beroperasi. Kebijakan tersebut ditegaskan dengan Undang-undang No. 24 Tahun 2004 tentang Lembaga
Penjamin Simpanan pasal 8 ayat 1 yang menyebutkan "Setiap Bank yang melakukan kegiatan usaha di wilayah negara republik Indonesia wajib menjadi peserta penjaminan, artinya semua bank yang beroperasi di Indonesia pasti menjadi anggota penjaminan simpanan sehingga dampak dari kebijakan ini tidak terlihat dari banyaknya deposit yang berhasil di himpun oleh bank.

Berbeda dengan Indonesia, Australia memiliki sistem penjaminan secara sukarela dimana peserta dapat memilih untuk menjadi atau tidak menjadi anggota daru penjamin simoanan. Di indoensia, semua bank yang beroperasi wajib menjadi peserta sebagai bentuk kebijakan preventif dari pemerintah untuk mencegah pengulangan krisi ekonomi yang terjadi pada periode 1997-1998. Berdirinya LPS menjadi lembaga independen yang bertugas untuk melakukan penjaminan simpanan agar menjaga kestabilan sistem perbankan dan mencegah depositor runs yang pernah terjadi pada periode krisis 19971998.

\section{SIMPULAN}

Berdasarkan hasil penelitian yang telah dilakukan melalui tahap pengumpulan data, pengolahan data, dan interpretasi data, hasil analisis mengenai pengaruh Capital Adequacy Ratio (CAR), Financing to Deposit Ratio (FDR), Non performing Financing (NPF) dan Deposit Insurance system (DIS) 
Luliansari, et al/Jurnal Ekonomi Syariah Teori dan Terapan Vol. 6 No. 12 Desember 2019: 2451-2470; FAKTOR-FAKTOR YANG MEMPENGARUH TERHADAP TINGKAT DEPOSIT BANK UMUM SYARIAH PERIODE 2011-2018

terhadap Tingkat Deposit, dapat disimpulkan sebagai berikut:

1. Dari uji † secara parsial menunjukan bahwa variabel Capital Adequacy Ratio (CAR) berpengaruh positif signifikan terhadap tingkat deposit. Tingginya nilai CAR dapat menambah kepercayaan masyarakat terhadap bank, karena bank telah menyediakan cadangan modal yang lebih besar untuk mencegah dari default.

2. Dari uji t secara parsial menunjukan bahwa variabel Non Performing Financing (NPF) Hasil tersebut menunjukkan kemampua manajemen bank dalam mengelolah kredit bermasalah yang diberikan bank dengan hasil yang positif mengindikasikan bank mampu menutupi pembiayaan bermasalah dengan tingkat deposit yang telah terkumpulkan (Setiawan, 2009).

3. Dari uji t secara parsial menunjukan bahwa variabel Deposit Insurance system (DIS) karenakan fenomena yang terjadi di indonesia kebijakan penjaminan simpanan diwajibkan untuk semua bank umum baik konvensional maupun syariah yang beroperasi. artinya semua bank yang beroperasi di Indonesia pasti menjadi anggota penjaminan simpanan sehingga dampak dari kebijakan ini tidak terlihat dari banyaknya deposit yang berhasil dihimpun oleh bank.
4. Secara simultan, semua variabel Capital Adequacy Ratio (CAR), Financing to Deposit Ratio (FDR), Non performing Financing (NPF) dan Deposit Insurance system (DIS) secara simultan berpengaruh signifikan terhadap Tingkat Deposit. Dengan menggunakan $\square=5 \% \quad$ kedua perbankan sama-sama memperoleh signifikansi=0,000, sehingga dapat disimpulkan semua variabel independen secara bersama-sama mempengaruhi variabel dependen.

\section{DAFTAR PUSTAKA}

Allen, L. dan A. Santomero. 1997. The Theory of Financial Intermediation.Journal of Banking and Finance 21: 1461-1486.

Ariefianto, M. D., \& Soepomo, S. (2013). Risk Taking Behavior Of Indonesian Banks: Analaysis On The Impact Of Deposit Insurance Cooperation Establishment. Buletin Ekonomi Moneter Dan Perbankan, 15(3), 325.

Arshad, M.K. (2011). Implementation of an Islamic Deposit Insurance System for The Islamic Financial Service Industry. Fourth Islamic Financial Stability Forum: Strengthening Financial Safety Nets in The Islamic Financial Service Industry. Kuala Lumpur.

Caprio, G., \& Klingebiel, D. (1999). Episodes of systematic and borderline financial distress. World Bank. 
Luliansari, et al/Jurnal Ekonomi Syariah Teori dan Terapan Vol. 6 No. 12 Desember 2019: 2451-2470; FAKTOR-FAKTOR YANG MEMPENGARUH TERHADAP TINGKAT DEPOSIT BANK UMUM SYARIAH PERIODE 2011-2018

Chernykh, L., \& Cole, R. A. (2010). Does deposit insurance improve financial intermediation? Evidence from the Russian experiment. Journal of Banking \& Finance, 35(2), 388-402.

Daulay, Raihanah. 2010. Analisis Pelayanan dan Bagi Hasil Terhadap Keputusan Menabung Nasabah pada Bank Syariah di Kota Medan. Jurnal Manajemen \& Bisnis, 10(01):8-10.

Dendawijaya, Lukman. "Manajemen Perbankan", Edisi Kedua, Ghalia Indonesia, Jakarta, 2009.

Diamond, D. W., \& Dybvig, P. H. (1983). Bank runs, deposit insurance, and liquidity. Journal of political economy, 91 (3), 401-419.

Fahmi I. (2012). Dinamika Struktur Pasar dan Perilaku Bank Serta Dampaknya Terhadap Kinerja Industri Perbankan Syariah. (Unpublished Dissertation). Bogor: Institut Pertanian Bogor.

Gujarati dan Porter. (1992). Dasar-dasar Ekonometrika. Jakarta. Salemba Empat

Gujarati, Damodar. (2012). Dasar-Dasar Ekonometrika. Jakarta: Salemba Empat

Karim, Adiwarman. 2007. Bank Islam Analisis Fiqh Dan Kevangan. Jakarta: PT. Raja Grafindo Persada.

Kunt A.D. \& E.J. Kane. (2002). Deposit insurance around the globe: Where does it work?.Journal of
Economic Perspectives. 16 (2):175195.

Lusian, S. et.al. (2015). Analisis Faktor-faktor Penyebab Pembiayaan Bermasalah di Bank Pembiayaan Rakyat Syariah CYZ periode 2009 2013. Finance and Banking Journal. 16 (1): 17-37.

Muhammad. 2005. Pengantar Akuntansi Syariah. Edisi 2. Jakarta: Salemba Empat.

Muhammad, D.W. \& A.Y. Lestari. (2015). Konsep Pengaturan Penjaminan Simpanan Nasabah Pada Bank Syariah. Jurnal Media Hukum. 22 (2): 274-293.

Nasution, M. (2012). Dampak Sistem Penjaminan Simpanan Terhadap Tingkat Deposit dan risk-taking Bank Umum di Indonesia Menggunakan Panel Data Analysis: Studi Empiris Periode 19952010. Unpublished Thesis). Jakarta: Universitas Indonesia.

Park, S. dan S. Peristiani. 1998. Market Discipline by Thrift Depositors. Journal of Money, Credit, and Banking 30: 347-364.

Rokhim, R. \& N. Wulandary. (2013). Pengaruh Penjaminan Simpanan, CAR, dan NPL Pada Tingkat Deposit, Risiko Moral Hazard, dan NIM. Jurnal Ekonomi dan Kevangan. 17 (4): 468-485.

Solihin. (2015). Analisis Kesiapan Perbankan Syariah Negara-negara ASEAN dalam Menghadapi 
Penerapan Masyarakat Ekonomi ASEAN Tahun 2015. (Unpublished Thesis). Bogor: Institut Pertanian Bogor.

Tsuru, K. (2003). Depositors' Selection of Banks and The Deposit Insurance System in Japan: Empirical Evidence and Its Policy Implications. Discussion Paper Series 03: E-024. Research Institute of Economy, Trade and Industry.

Ulfah, M. 2010. Analisa Perkembangan Asset, Dana Pihak Ketiga (DPK), dan Pembiayaan Perbankan Syariah di Indonesia. Skripsi: Universitas Gunadarma
Vale, B. (2011). Effects of Higher Equity Ratio on a Bank's Total Funding Costs and Lending. Oslo: Norges Bank.

Widigdo, et.al. (2016). Business process reengineering of funding on Indonesia's Islamic bank. Allqtishad: Jurnal Ilmu Ekonomi Syariah (Journal of Islamic Economics). 8 (1): 19-32.

Zarruk, E. R. dan J. Madura. 1992. Optimal Bank Interest Margin Under Capital Regulation and Deposit Insurance. The Journal of Financial and Quantitative Analysis: 143-149. 